УДК 631.51:631.8:631.11, DOI 10.31210/visnyk2018.04.12

(C) 2018

Саюк О. А., кандидат сільськогосподарських наук, Плотницька Н. М., кандидат сільськогосподарських наук, Павлюк I. O., аспірант

(науковий керівник - кандидат сільськогосподарських наук О. А. Саюк)

Житомирський національний агроекологічний університет

Ткачук В. П., кандидат сільськогосподарських наук

Інститут сільського господарства Полісся НААН України

\title{
ВПЛИВ СПОСОБІВ ОСНОВНОГО ОБРОБІТКУ ГРУНТУ ТА СИСТЕМ УДОБРЕННЯ НА УРОЖАЙНІСТЬ ПШЕНИЦІ ОЗИМОЇ
}

\section{Рецензент - кандидат сільськогосподарських наук А. В. Бакалова}

В умовах Полісся Украӥни досліджено вплив способів обробітку трунту та систем удобрення на урожайність зерна пшениці озимої сорту Колос Миронівщини. Встановлено, щзо урожайність зерна пшениці озимої залежить від способу обробітку трунту та системи удобрення. Дослідженнями встановлено, щзо оптимальним способом обробітку трунту в разі вирошування пшениці озимої в умовах Полісся Украӥни є оранка на глибину 18-20 см. Використання інших досліджуваних способів обробітку трунту призводить до втрат урожайності зерна в межах 0,08$0,56 \mathrm{~m} / 2$. Використання добрив сприяє підвищченню урожайності зерна пшениці озимої сорту Колос Миронівщчини. Застосування органічної системи удобрення сприяє підвищенню урожайності зерна в межах 15,29-35,63\%, органо-мінеральної - в межах 28,36-44,44\%, за різних систем обробітку трунту у порівнянні із варіантами без удобрення.

Ключові слова: пшеничя озима, урожайність, обробіток трунту, удобрення.

Постановка проблеми. За посівними площами в Україні пшениця озима займає перше місце. Ця культура зазвичай вирощується на зерно та потребує перезимівлі при понижених температурах. Сприятливий хімічний склад зерна пшениці озимої дає змогу виготовляти високоякісні продукти харчування. На відміну від інших зернових, ця культура має великий вміст білку, кількість якого в зерні пшениці м'яких сортів, залежно від сорту та умов вирощування, може становити 13-15\%. Пшениця озима містить значну кількість вуглеводів та крохмалю, вітаміни В1, В2, РР, Е та провітаміни А, D, амінокислоти - лізин, триптофан, валін, метіонін, треонін, фенілаланін, гістидин, аргінін, лейцин, ізолейцин. Білки пшениці добре засвоюються організмом людини. Широко також використовуються у галузі тваринництва пшеничні висівки та солома $[5,6]$.

Під час вирощування пшениці озимої застосовують комплекс сучасних інтенсивних технологій, зокрема підбір правильних обробітків грунту, використання інтенсивних сортів, системи засобів захисту рослин від шкідливих організмів тощо. Збільшення урожайності зерна пшениці озимої можливе лише за умов дотримання технології вирощування та комплексу інших заходів, що сприяють підвищенню стійкості рослин до несприятливих факторів навколишнього середовища $[8,13,14]$.

Аналіз останніх досліджень і публікацій, у яких започтаковано розв'язання проблеми. Значний вплив на урожайність пшениці озимої має родючість грунту, що залежить від багатьох факторів, проте основними під час вирощування сільськогосподарських культур $\epsilon$ обробіток грунту та система удобрення, які сприяють підвищенню родючості грунту, до якої вибаглива пшениця озима. Правильний підбір обробітку грунту та чергування культур у сівозміні сприяє зменшенню ураження культурних рослин шкідниками, пошкодження хворобами, знижує забур'яненість, що $\epsilon$ важливим фактором під час вирощування сільськогосподарських культур та отриманні високого урожаю $[4,9]$.

Оптимально підібраний обробіток грунту сприяє розподілу поживних речовин та рослинних решток у шарі грунті. Основний обробіток грунту затримує вологу, збагачує повітрям і поживними речовинами грунт, що є дуже важливим у рості та розвитку культурних рослин. Завдяки цьому формується структура орного шару, зберігається волога, зменшується забур'яненість грунту, приорюються рослинні рештки та добрива, ущільнюється орний шар, а також підвищується захист від водної та вітрової ерозії $[10,13]$.

Плоскорізний обробіток грунту знищує коренепаросткові бур'яни: осот рожевий, берізку польову та інші. Доречним $\epsilon$ цей обробіток грунту в посушливі роки, оскільки він зберігає вологу шляхом ущільнення та підвищує урожайність сільськогосподарських культур. 


\section{СІЛЬСЬКЕ ГОСПОДАРСТВО. РОСЛИННИЦТВО}

Плоскорізний обробіток немає переваг перед основним обробітком, проте якщо його постійно використовувати та не вносити добрива, урожайність сільськогосподарських культур може зменшуватись $[9,14]$. Відомо, що систематичний безполицевий обробіток грунту із внесенням різних доз мінеральних добрив призводить до зниження урожайності пшениці озимої за рахунок збільшення забур'яненості посівів та зменшення запасів доступної вологи у грунті [8].

Разом із урожаєм 3 грунту озима пшениця виносить такі поживні речовини як азот, фосфор, калій. Лімітуючим фактором впливу на урожайність і якість врожаю є добрива. Саме завдяки системі удобрення можна регулювати родючість грунту та відновлювати іiі. Внесення макро- та мікроелементів сприяє кращому розвитку кореневої системи, підвищує зимо- та морозостійкість, сприяє розвитку вегетативної поверхні рослин тощо $[2,14]$.

Кращому розвитку кореневої системи сприяють фосфорно-калійні добрива, які також збільшують вміст цукрів у рослинах, підвищують їх морозостійкість. Цінними для росту і формування зерна та збільшення білка в рослинах $є$ азотні добрива. Використання науково обгрунтованих доз мінеральних добрив під основні сільськогосподарські культури покращує живлення рослин, проте внесення добрив у кількостях, які перевищують фізіологічну потребу рослин, не призводить до подальшого збільшення урожайності і супроводжується погіршенням якості продукції. Застосування органічної системи удобрення сприяє підвищенню урожайності культур, проте наявність насіння бур'янів та органів їх вегетативного розмноження у органічних добривах призводить до збільшення забур'яненості посівів, що може негативно вплинути на урожайність та якість сільськогосподарської продукції [4, 12].

Проведені в умовах Правобережного Лісостепу дослідження щодо визначення впливу обробітків грунту і систем удобрення на урожайність пшениці озимої показали, що застосування класичного і плоскорізного обробітків грунту із застосуванням повного внесення мінеральних добрив 3 локальним внесенням $\mathrm{N}_{30}$ та підживленням $\mathrm{N}_{15}$ дає можливість отримати приріст урожаю зерна пшениці озимої в межах 0,95-0,98 т/га [11].

Саме тому метою наших досліджень стало визначенні впливу застосування способів обробітку грунту та систем удобрення на зміни урожайності пшениці озимої в умовах Полісся України.

Основним завданням було дослідження зміни урожайності зерна пшениці озимої залежно від застосування різних способів основного обробітку грунту та систем удобрення.

Матеріали і методи досліджень. Дослідження проводилися протягом 2016-2017 рр. в умовах дослідного поля Інституту сільського господарства Полісся НААН України (с. Грозино Коростенського району Житомирської області) у стаціонарному та тимчасових дослідах, які розміщені на типовому для зони Полісся дерновосередньопідзолистому супіщаному грунті. У дослідженнях використовували пшеницю озиму сорту Колос Миронівщини.

Дослід закладено методом розщеплених ділянок: на ділянках першого порядку 3 посівною площею $529 \mathrm{~m}^{2}$ вивчалися способи обробітку грунту, на ділянках другого порядку з обліковою площею $72 \mathrm{~m}^{2}$ - системи удобрення. У досліді вивчалося чотири варіанти обробітку грунту (оранка, 18-20 см; оранка, 12-14 см; дискування, 8-10 см; плоскорізний обробіток, 18-20 см) на трьох фонах удобрення (без добрив; органомінеральна система удобрення; органічна система удобрення). Повторність досліду - триразова.

Облік врожаю здійснювали ваговим методом згідно з «Методикою державного сортовипробування сільськогосподарських культур». Статистичний аналіз даних проводили дисперсійним методом 3 використанням комп'ютерних програм «Statistica 6,0» згідно з методиками, викладеними в працях Б. А. Доспєхова [3, 7].

Результати досліджень. У результаті проведених досліджень встановлено, що системи застосування добрив та обробіток грунту спричиняють неоднозначний вплив на урожайність пшениці озимої. Встановлено, що урожайність зерна пшениці озимої у контрольному варіанті (без застосування добрив) становила 2,642,68 т/га у випадку застосування безполицевого обробітку грунту та 2,61-2,76 т/га - в разі обробітку з обертанням скиби (табл. 1).

Застосування добрив за різних систем обробітку грунту сприяло підвищенню урожайності зерна пшениці озимої у межах 3,09-3,96 т/га. У випадку застосування безполицевого обробітку грунту урожайність пшениці озимої знижувалась, порівняно обробітками 3 обертанням скиби, не залежно від системи удобрення. Втрати в урожайності на контрольному варіанті за різних способів обробітку грунту становили 2,90$5,43 \%$, у порівнянні з оранкою на глибину 18 20 см. Застосування органо-мінеральної системи удобрення за різних способів обробітку грунту призводило до зниження урожайності зерна пшениці озимої на $0,19-0,56 \mathrm{t} / г$, порівняно із оранкою на глибину $18-20 \mathrm{~cm}$. 
СІЛЬСЬКЕ ГОСПОДАРСТВО. РОСЛИННИЦТВО

1. Вилив способів основного обробітку трунту та удобрення на урожайність зерна пшениці озимої, 2016-2017 рр.

\begin{tabular}{|c|c|c|c|c|c|c|}
\hline \multirow{3}{*}{$\begin{array}{c}\text { Система } \\
\text { удобрення }\end{array}$} & \multirow{3}{*}{$\begin{array}{c}\text { Спосіб } \\
\text { обробітку грунту }\end{array}$} & \multirow{3}{*}{$\begin{array}{l}\text { Урожай- } \\
\text { ність, т/га }\end{array}$} & \multicolumn{4}{|c|}{ Приріст урожаю від } \\
\hline & & & \multicolumn{2}{|c|}{ обробітку } & \multicolumn{2}{|c|}{ добрив } \\
\hline & & & т/га & $\%$ & т/га & $\%$ \\
\hline \multirow{4}{*}{$\begin{array}{l}\text { Без добрив } \\
\text { (контроль) }\end{array}$} & Оранка, 18-20 см & 2,76 & - & - & - & - \\
\hline & Оранка, 12-14 см & 2,61 & $-0,15$ & $-5,43$ & - & - \\
\hline & Дискування, 8-10 см & 2,68 & $-0,08$ & $-2,90$ & - & - \\
\hline & $\begin{array}{c}\text { Плоскорізний обробіток, } \\
18-20 \text { см }\end{array}$ & 2,64 & $-0,12$ & $-4,35$ & - & - \\
\hline \multirow{4}{*}{$\begin{array}{c}\text { Органо- } \\
\text { мінеральна }\end{array}$} & Оранка, 18-20 см & 3,96 & - & - & 1,20 & 43,48 \\
\hline & Оранка, 12-14 см & 3,77 & 0,19 & $-4,80$ & 1,16 & 44,44 \\
\hline & Дискування, 8-10 см & 3,44 & $-0,52$ & $-13,13$ & 0,76 & 28,36 \\
\hline & $\begin{array}{c}\text { Плоскорізний обробіток, } \\
18-20 \text { см } \\
\end{array}$ & 3,4 & $-0,56$ & $-14,14$ & 0,71 & 28,79 \\
\hline \multirow{4}{*}{ Органічна } & Оранка, 18-20 см & 3,47 & - & - & 0,93 & 25,72 \\
\hline & Оранка, 12-14 см & 3,54 & 0,07 & 2,02 & 0,41 & 35,63 \\
\hline & Дискування, 8-10 см & 3,09 & $-0,38$ & $-10,95$ & 0,52 & 15,29 \\
\hline & $\begin{array}{c}\text { Плоскорізний обробіток, } \\
18-20 \text { см } \\
\end{array}$ & 3,16 & $-0,31$ & $-8,93$ & 0,74 & 19,70 \\
\hline \multirow{3}{*}{\multicolumn{2}{|c|}{$\begin{aligned} \mathrm{HIP}_{05} & \text { для обробітку } \\
& \text { для добрив } \\
& \text { для фактора взаємодії }\end{aligned}$}} & \multicolumn{5}{|c|}{0,08} \\
\hline & & \multicolumn{5}{|c|}{0,18} \\
\hline & & \multicolumn{5}{|c|}{0,20} \\
\hline
\end{tabular}

Нашими дослідженнями встановлено позитивний результат щодо підвищення урожайності зерна пшениці озимої в разі використання органічної та органо-мінеральної системи удобрення. Використання добрив призводило до збільшення урожайності зерна пшениці озимої на 25,72$44,44 \%$ у варіантах із обертанням скиби та на $15,29-28,7 \%$ - за безполицевих обробітках грунту.

Найбільшу урожайність, що становила 3,96 т/га, нами отримано в разі проведення оранки на глибину 18-20 см за органо-мінеральної системи удобрення.

Висновки. Способи обробітку грунту мають значний вплив на урожайність зерна пшениці озимої. Встановлено, що оптимальним способом обробітку грунту під пшеницю озиму є оранка на глибину 18-20 см. Використання інших досліджуваних обробітків призводить до зниження

\section{БІБЛІОГРАФІЯ}

1. Влияние безотвальных обработок на дифференциацию плодородия / Ю. В. Буденный, Ю. А. Полеско, А. М. Слепщов [и др.] // Химизация сельского хозяйства. -1990 . - № 3. - С. 52-55.

2. Влияние удобрений на интенсивность баланса NPK в почве и урожайность культур / М. Х. Шири- урожайності зерна пшениці озимої в межах $0,08-$ $0,56 \mathrm{~T} /$ га.

Використання мінеральних та органічних добрив за різних способів обробітку грунт, сприяє підвищенню урожайності зерна пшениці озимої на $0,41-1,2$ т/га, порівняно із неудобреним фоном.

В умовах Полісся України під час вирощування пшениці озимої доцільно проводити оранку на глибину 18-20 см та використовувати органомінеральну систему удобрення, що забезпечує формування найвищого врожаю зерна в межах 3,96 т/га.

Подальші дослідження будуть спрямовані на більш детальне вивчення впливу різних способів обробітку грунту та систем удобрення на урожайність культур сівозмін в умовах Полісся України.

нян, В. К. Бугаевский, В. М. Кильдюшкин, Н. Г. Роианов // Земледелие. - 2008. - № 6. - С. 18-19.

3. Доспехов Б.А. Методика полевого опыта : (С основами стат. обраб. результатов исслед.) / Б. А. Доспехов. - 5-е изд., доп. и перераб. - М. : Агропромиздат, 1985. $-351 \mathrm{c}$. 
4. Забродкин А. А. Влияние различных способов обработки почвы на урожайность и качество зерна озимой пшеницы / А. А. Забродкин // Вестник Орел ГАУ. - 2012. - № 2 (35). - С. 28-31.

5. Лыков А. М. Биология почв и урожай / А. М. Лыков, А. Ф. Сафонов, 3. Тарабаши // Земледелие. -1990 . - № 9. - С. 20-22.

6. Лихочвор В. В. Ресурсоощадна технологія вирощування озимої пшениці для умов Західної України: Монографія. - Львів: НВФ Українські технології. - 1997. - 204 с.

7. Методика державного сортовипробування сільськогосподарських культур / Держ. коміс. України по випробуванню та охороні сортів рослин; Під ред. В. В. Волкодава. - К., 2000 - 100 с.

8. Ображій С. В. Урожайність культур за різних систем основного обробітку грунту та рівнів удобрення в зернопросапній сівозміні центрального Лісостепу України / С. В. Ображій // Вісник аграрної науки Причорномор'я. - 2015. - Вип. 3. - C. 131-142

9. Обробіток грунту у адаптивно-ландшафтних системах землеробства / Шувар I. А., Гудзь В. П., Печенюк В. І. [та ін.]. - Львів, 2011.

\section{ANNOTATION}

Saiuk O. A., Plotnytska N. M., Pavliuk I. O., Tkachuk V. P. Influence of soil tillage methods and fertilization systems on winter wheat yield.

Influence of soil tillage methods and fertilization systems on yield of winter wheat variety Kolos Myronivshchyny in the conditions of Polissia in Ukraine has been investigated. The research was conducted during the period of 2016-2017 under the conditions of the experimental field of the Institute for Agriculture of Polissia NAAS.

in the stationary and temporary experiments, which are located on the typical sod mesopodzol sandy soils for the Polissia region. Four types of soil tillage were studied in the experiment (plowing, 18$20 \mathrm{~cm}$, plowing, $12-14 \mathrm{~cm}$, disc plowing, $8-10 \mathrm{~cm}$, subsurface plowing, $18-20 \mathrm{~cm}$ ) on three fertilizing backgrounds (no fertilizers, organo-mineral fertilization system; organic fertilization system). The experiment was laid by the method of split areas: methods of soil tillage were studied on the firstorder areas with sown area of $529 \mathrm{~m}^{2}$, fertilization systems were studied on the second-order areas with an accounting area of $72 \mathrm{~m}^{2}$. The repetition of the experiment is three -time.

It has been established that yield of winter wheat
$-382 \mathrm{c}$.

10. Пабат I. А. Грунтозахисна система землеробства / I. А. Пабат. - К. : Урожай, 1992. - 180 с.

11. Пелех Л. В. Вплив обробітків грунту та удобрення урожайність пшениці озимої в умовах Правобережного Лісостепу України / Л. В. Пелех. // Зб. наук. праць ВНАУ. Серія: Сільське господарство та лісівництво. - 2017. Том 1, Вип. 6. - С. 62-70

12. Шедєй Л. О. Вирощування озимої пшениці за різних систем удобрення / Л. О. Шедєй, Р. В. Акімова // Вісник ХНАУ. Сер. Агрохімія. - 2009. - № 2. - C. 43-47.

13. Шикули М. К. Відтворення родючості грунтів у грунтозахисному землеробстві : наук. монографія / під ред. М. К.Шикули. - К. : Оранта, 1998. $-680 \mathrm{c}$.

14. Шикітка В. I. Вплив систем обробітку й удобрення на продуктивність сівозміни / В. І. Шикітка, Г. Й. Сеньків, А. О. Зубицька // Землеробство : міжвід. тем. наук. зб. - К. : Аграрна наука, 2003.- Вип. 75. - С. 26-32.

depends on the soil tillage method and fertilization system. Applying field-free soil tillage methods of winter wheat yield decreased comparing to the tillage with the rotation of furrow slice, regardless of the fertilization system. The research has established that the optimal soil tillage method during winter wheat cultivation under the conditions of Polissia is plowing to a depth of $18-20 \mathrm{~cm}$. The use of other investigated tillage methods results in losses of grain yield within the range of $0.08-0.56 \mathrm{t} / \mathrm{ha}$. Fertilizers application causes increase of yield of winter wheat variety Kolos Myronivshchyny. Application of organic fertilization system contributes to increase of grain yield in the limits of $15.29-35.63 \%$, organo-mineral system - within the limits of 28.36$44.44 \%$, with different systems of soil tillage in comparison with the variants without fertilization. It is reasonably to plow up to a depth of $18-20 \mathrm{~cm}$ and use of organo-mineral fertilization system, which ensures the formation of the highest grain yield in the range of $3.96 \mathrm{t} / \mathrm{ha}$ in the conditions of Polissia of Ukraine.

Key words: winter wheat, yield, soil tillage, fertilization. 